\title{
A Historical Perspective on the Development of an Ethnic Minority Consciousness in the Spanish-Language Press of the Southwest
}

\author{
Nicolás Kanellos \\ University of Houston
}

Various scholars have treated ethnic newspapers in the United States as if they all have evolved from an immigrant press. While one may accept their analysis of the functions of the ethnic press, there is a substantial and qualitative difference between newspapers that were built on an immigration base and those that developed from the experience of colonialism and racial oppression. Hispanics were subjected to "racialization"ii for more than a century through such doctrines as the Spanish Black Legend and Manifest Destiny during the nineteenth and early twentieth century. They were conquered and incorporated into the United States and then treated as colonial subjects as is the case of Mexicans in the Southwest and the Puerto Ricans in the Caribbean. Some were incorporated through territorial purchase as was the case of the Hispanics in Florida and Louisiana. (I would also make a case that, in many ways, Cubans and Dominicans also developed under United States domination in the twentieth century.) The subsequent migration and immigration of these peoples to the United States was often directly related to the domination of their homelands by the United States. Their immigration and subsequent cultural perspective on life in the United States, of course, has been substantially different from that of European immigrant groups. Hispanic native or ethnic minority perspective has manifested itself in the political realm, often as an attitude of entitlement to civil and political rights.

Many of the Hispanic newspapers which developed in the Southwest after the Mexican War was concluded in 1848 laid the basis for the Hispanics in the United States to see themselves as an ethnic minority within this country. While the 


\section{Ethnic Studies Review Volume 21}

origins of their journalistic endeavors date back to the period before the all-important signing of the peace treaty between the United States and Mexico, it was the immediate conversion to colonial status of the Mexican population in the newly acquired territories of California, New Mexico and Texas that made their journalistic efforts a sounding board for their rights first as colonials and later as "racialized" citizens of the United States. Had there been native Spanish-language newspapers in operation in Florida or Louisiana and/or a sufficiently large population to sustain them at the time of their take-over by the U.S., the Hispanic ethnic minority press might have begun there as they became territories and later states in the Union.

Although the printing press was not introduced to California and New Mexico until 1834, during the Mexican period, the society there, as in Texas, was sufficiently literate to sustain a wide range of printing and publishing once the press was allowed.iii Newspaper publication in what became the Southwest in the United States started in 1813 with the publication of La Gaceta de Texas (The Texas Gazette) and El Mexicano (The Mexican), papers published to support Mexico's movement for independence from Spain. In 1834 and 1835. Spanish-language newspapers began to appear in these northern provinces of Mexico: Santa Fe's El Crepúsculo de la Libertad (The Dawn of Liberty)iv and Taos' El Crepúsculo (Dawn, 1835-?).` Prior to the U.S. conquest, these other newspapers were published in New Mexico: La Verdad (The Truth, 1844-1845) and its successor, El Payo de Nuevo México (The New Mexico Countryman, 1845).

Beginning with the American presence during the outbreak of the Mexican War in 1846, various newspapers began publishing in English and bilingually in English and Spanish in California and New Mexico. Numerous English-language newspapers had been publishing in Texas for Anglo-Texan communities since just before the proclamation of the Texas Republic in 1836, with newspapers in Stephen F. Austin's colonies dating back to as early as 1824 . From California to Texas the norm among many of these first Anglo-owned newspapers was to publish in English and Spanish. In New Mexico, publishing only in Spanish or bilingually was a necessity for the Anglo owners of the newspapers because the vast majority of 
the inhabitants of the territory were Spanish speakers. In California, newspapers received a subsidy from the state as well as from some cities for printing laws in Spanish, as the state constitution required laws to be issued in both languages.vi One can imagine how this developed into a profitable enterprise once the Spanish-language market was identified and cultivated. Indeed, the Spanish-language section of Los Angeles' Star grew into La Estrella de Los Angeles and then as a separate newspaper: El Clamor Público (The Public Clamor, 1855-1859). From San Francisco's The Californian (1846-1848), the first Anglo-American newspaper in Alta California, to New Mexico's Santa Fe Republican (1847-?), to Brownsville's La Bandera (184?-163?) and to The Corpus Christi Star (1848-?), the Anglo-established press was a bilingual institution. The Anglo-American press in the newly acquired territories as a general rule provided translation of the English-language news in Spanish. However, according to Stratton, only about twelve percent of the journalists employed by these newspapers were Hispanics. vii This imbalance and the predominance of Anglo ownership and administration of the press was typical of the colonial condition of Hispanics in the Southwest:

...the conquering group establishes media for the conquered group but then controls the media by restricting employment opportunities, establishing a dual labor market, controlling the context of the news, and delivering even that news a week later to members of the conquered group. More concise description of the neo or internal colonial control of the press could not be more clear.viii

Even Spanish-language newspapers that were published independently by Hispanics were often dependent on the Anglo business community and the economic and political power structures for their existence. Many of the Hispanic publishers, drawn from the upper classes, were able to survive in business by working within the system, not attacking it in the name of ethnic or civil rights. ${ }^{i x}$ In fact, many Spanish-language newspapers maintained links to their English-language counterparts 


\section{Ethnic Studies Review Volume 21}

and to the Anglo establishment. Los Angeles' La Crónica (The Chronicle, 1872-1892?), in fact, advertised itself as the city's "official" newspaper, principally because it held a city printing contract. Still other Spanish-language newspapers from California to Texas were affiliated with the political parties and only published around election time to support party platforms and candidates in the Hispanic communities. All of this leads Gutierrez to conclude the, "The lines of dependency, coupled with the content of newspapers, would seem to indicate that attempts were made to harness the Spanish-language press and utilize it as an instrument of social control."x

Despite this attempt to control the Hispanic population through the press, the Anglo-Americans' migration into the region brought with it from the East advanced technology and equipment. Ironically, this directly resulted in printing presses coming into Hispanic hands as never before and the subsequent founding of more and more Spanish-language newspapers to serve the native Hispanic population of the Southwest. And when the railroad reached the territories, dramatic changes occurred as a consequence of greater access to machinery and technology as well as better means of distribution for print products. The last third of the century, thus, saw an explosion of independent Spanish-language publishing by Hispanics.

\section{New Mexico}

Drawing comparably fewer Anglo settlers and entrepreneurs than California and Texas and because of its larger Hispanic population, New Mexico was the territory that first developed a widespread independent native Hispanic press. No not only did more Hispanics live there, but they also lived in a more compact area and with comparably less competition and violence from Anglo newcomers. The Nuevomexicanos were able to hold onto more lands, property and institutions than did the Hispanics of California and Texas. Control of their own newspapers became essential in the eyes of Hispanic intellectuals and community leaders in the development of Nuevomexicano identity and self-determination in the face of 
adjusting to the new culture that was foisted upon them during the territorial period. Nuevomexicanos were in a double-bind. On the one hand, they wanted to control their own destiny and preserve their own language and culture while enjoying the benefits and rights of the advanced civilization that the United States had to offer through statehood. On the other hand, they immediately became aware of the dangers of Anglo-American cultural, economic and political encroachment in New Mexico. According to Meléndez, many of the intellectual leaders, especially newspaper publishers, believed that the native population would only advance, learn to protect itself, and merit statehood through education; they saw the newspapers as key to the education and advancement of the natives as well as to the protection of their civil and property rights. Nuevomexicanos felt the urgency to empower themselves in the new system and to retain some of the power they had under Mexico while Washington delayed statehood for more than fifty years, in expectation, of Anglos achieving a numerical and voting superiority in the territory. $\mathrm{xi}$

In the decade following the arrival of the railroad in 1879, native Hispanic journalism increased dramatically in the New Mexico territory. According to Meléndez, a true flowering of Nuevomexicano periodicals followed in the 1890s, when some thirty-five Spanish-language newspapers were being published.xii The result was that the English-language and bilingual newspapers were left to serve a mostly Englishspeaking elite, while the Spanish-language papers were serving the rest of the inhabitants. By 1900, every settlement along the Rio Grande corridor had Spanish-language newspapers, and the practice extended into southern Colorado and to Texas. The most populous cities supported the greatest press activity: Las Cruces, Albuquerque, Santa Fe and Las Vegas.xiii From 1879 to the year New Mexico was admitted as a state of the Union, 1912, more than ninety Spanish-language newspapers were published in New Mexico.xiii By 1891, native Hispanic journalism had become so widespread and intense that a newspaper association was founded, La Prensa Asociada Hispano-Americana, to set up a network of correspondents, to share resources and to facilitate reprinting items from each member newspaper in a kind of informal syndica- 


\section{Ethnic Studies Review Volume 21}

tion. Thus in a few short decades some native inhabitants of what had been a backwater province under Mexico and a frontier colony under the United States had been transformed into intellectuals and activists utilizing print and transportation technologies. They took the lead in ushering their community into the twentieth century and statehood.

How and why did this occur? Meléndez posits that there was a political exigency to preserve their language, culture and civil rights. He writes: "The 'communications circuit' used by local journalists functioned, on the one hand, as counterhegemonic discourse that subverted assaults on Mexicano culture, and on the other, as a way to channel the power of literacy to change society."xiv The new technology that Nuevomexicanos adopted did not represent fundamental cultural change; rather it empowered cultural expression that was long held and deeply rooted in the area. As Meyer put it, "The Spanish-language press, as a bridge between tradition and modernity and as an advocate of its people in Hispanic New Mexico, served as a counter discourse contesting the Anglo myth of the frontier and claiming a space for otherness in American society. In its pages one finds the multivocal reality of neomexicano cultural identity that resists monolithic definition." $x v$

Meléndez documents how the Nuevomexicano journalists set about taking control of their social and cultural destiny by constructing what they saw as a "national" culture for themselves,which consisted of using and preserving the Spanish language, formulating their own version of history and their own literature, all of which would ensure their self-confident and proud entrance to the Union. From within the group of newspaper publishers and editors sprung a cohesive and identifiable corps of native creative writers, historians, and publishers who elaborated on a native and indigenous intellectual tradition that is the basis of much of the intellectual and literary work of Mexican Americans today. In addition, the young journalists quite often went on to become leaders in New Mexico trade, commerce, education and politics-a legacy still felt today.

The cultural nationalism of these native journalists, of course, sprung from the necessity to defend their community 
from the cultural, economic and political onslaught of the "outsiders." Their newspapers were to provide "la defense de nuestro pueblo y nuestro país" (the defense of our people and our homeland). And, in keeping with their community leadership, their defense of cultural and civil rights was often issued in front page editorials that in no uncertain terms made it clear that Nuevomexicanos had to assume a posture of defense in order to survive and that part and parcel of the defense was the furthering of education and cultural solidarity. Typical of these editorials were the many printed by Enrique $\mathrm{H}$. Salazar, the founding editor of La Voz del Pueblo (The Voice of the People, 1889-1924) and later El Independiente (The Independent, 1894-192?), in which he blamed the social decline of Nuevomexicanos on Anglo-American domination and racism. Salazar clearly envisioned a battle of cultures and rights:

Our periodical... will continue its watch to protect the interests, honor and advancement of all of the segments of our great Territory. The well-being of the people of New Mexico and principally of the native population will be at every instance the powerful motive that will impel with great vigor our efforts in the publication of our weekly. We are the foot soldiers of the community, guarding its rights. xvi

One magazine that stood out in furthering the literary goals of the Nuevomexicnos was the Revista llustrada (The Illustrated Review), which Camilo Padilla founded in EI Paso, Texas, in 1907 and continued to publish in Santa Fe, New Mexico, from 1917 to 1931 ? Revista llustrada was ahead of its time in identifying and furthering a Hispanic ethnic minority culture in the United States. Unlike New York's Revista Ilustrada, which in the 1880s and 1890s envisioned an international, pan-Hispanic readership, New Mexico's squarely situated itself in the home, although it tried to connect the culture of New Mexico and the Southwest to that of Mexico and the greater Hispanic world. In addition to publishing poetry, stories and history, the magazine offered space to Nuevomexicano intellectuals to ponder the fate of their culture.

Among the collaborators were such notables as 


\section{Ethnic Studies Review Volume 21}

Nuevomexicano historian Benjamin M. Read, poet and novelist Eusebio Chacón and linguist and professor Aurelio M. Espinosa. In its furtherance of the Spanish language and Hispanic culture, the Revista llustrada included the works of some of the outstanding Spanish American literary figures of the time and advertised books of European and Latin American literature in Spanish that could be bought directly from the magazine, including works by Cervantes, Dumas, Fernández de Lizardi, Hugo, Isaacs and Verne; also appearing on the lists were works of regional and folk literature. After 1925, Padilla's cultural work went far beyond the pages of the magazine to the founding and administration of El Centro de Cultura in Santa $\mathrm{Fe}$, a center for cultural, literary and social events, but foremost a place for native art and culture practice. Another activity brought Padilla's nativist concerns directly into the political realm: he was one of the organizers of a third party, El Club Político Independiente (The Independent Political Club) to represent the concerns of the native Nuevomexicanos.xvii

As Meléndez asserts, the promotion of a "national" literature and a "national" history by these editors and writers demonstrates that as early as the late nineteenth century the Nuevomexicanos were seeing themselves as a national minority of the United States. This idea was furthered by the regionwide Hispanic American Press Association through exchanges with newspapers in Texas and California and by the awareness of region-wide dispossession and proletarization of the Mexican-origin population. That they recognized the value of their own local history, folklore, and literature and had elevated it to print was a conscious part of this minority identity formation that was taking place. They simply needed to preserve an identity within the bounds of an overwhelming and pervasive Anglo-American national culture.

\section{California}

Soon after the influx of Anglo-Americans occasioned by the Gold Rush and statehood in 1850, the native Hispanic population of California became overwhelmed and was quickly relegated to a minority status. xvii The post-Civil War migration further accentuated the immigration of Anglos, the arrival of the 
railroads, the breaking up of the Californio ranches, and the conversion of the economy to American capitalism and the native population into a proletariate.

Almost as soon as newspaper ownership came into the hands of the native Hispanic population of California, an ethnic minority consciousness began to develop. xx When Francisco P. Ramírez took the Spanish section from the Los Angeles Star and founded a separate newspaper, El Clamor Público (The Public Clamor, 1855-1559), he created a landmark in awareness that Hispanics in California had been and were being treated as a race apart from the Europeans and Americans who had immigrated into the area. They were being dispossessed of their lands and rights and they were being converted into a proletariate. In addition to covering California and U.S. news, El Clamor Público also maintained contact with the Hispanic world outside California and attempted to present an image of refinement and education that demonstrated the high level of civilization achieved throughout Hispanic world. This, in part, was a defensive reaction to the negative propaganda of Manifest Destiny which had characterized Mexicans and other Hispanics as unintelligent and uneducated barbarians incapable of developing the lands and natural resources of the West and thus justified these lands and resources being wrested from their hands by the superior newcomers. El Clamor Público depended on subsidy from the city of Los Angeles and had strong ties to the Anglo-American business community in the city. In addition, it was aligned with the Republican Party. Ramírez and his paper were also staunch supporters of learning English; xix not only was it important for business but also for protecting the Californios' rights. These pro-business and Republican stances, nevertheless, did not stop Francisco P. Ramírez from assuming an editorial stance in defense of the native population

Only seventeen-years-old when he took the helm of $E l$ Clamor Público, Ramírez was a supporter of Mexicans learning the English language, of statehood and of the United States Constitution from the outset. However, his indignation increased as the civil and property rights of the Californios were not being protected by that Constitution he loved so much. He became a consistent and assiduous critic, attempt- 


\section{Ethnic Studies Review Volume 21}

ing to inspire the Hispanics to unite in their defense and to implore the authorities to protect the Hispanic residents of California, who were being despoiled, even lynched. In his August 28, 1855, editorial entitled "Inquisición" (Inquisition), Ramírez decried the vigilantism of the Americans, who had come to displace the native population and their penchant for lynching Mexicans:

This procedure used by the American people has filled all of the descendants of the Spanish race with indignation. The authorities of a country should care for the security of its citizens, and it is incumbent upon them to judge and punish the criminal; but the infuriated mob has no right to take the life of a man without finding out if he has committed the crime of which he is accused.... Since 1849, there has existed an animosity between Mexicans and Americans, so foreign to a magnanimous and free people to such an extent that these [Americans] have wished with all their heart that all of the Mexicans had just one neck so that it could be cut off all at once. They [the Mexicans] have suffered many injustices, and they have especially been mistreated and abused with impunity in the mines. If a Mexican has the misfortune to place a suit in a court of this State, he is sure to lose it. It is impossible to negate this assertion because we know this has befallen many unfortunates who in spite of the efforts they have made to obtain their rights and impartial justice.xx

Ramírez was instrumental in raising consciousness about this injustice, and oppression was not an isolated and local phenomenon. He reprinted news and editorials from around the state and focused on the role of the Spanish-language press in building this consciousness. For example, in his 23 February 1886 editorial entitled "El Periodismo en California" (Journalism in California), Ramírez reprinted D. J. Jofre's editorial from San Francisco's El Eco del Pacífico (The Pacific 
Echo, 1856-18?) which emphasized the role of the press in protecting la raza in California:

Nowhere is the need for a Spanish-language newspaper more evident than in the state of California ..., as Americans and as individuals of the noble Spanish race to which we belong, we believed it our duty ... to raise our powerful voice with the armaments of reason, in order to denounce before the supreme court of public opinion the abuses and injury that have been and continue to be with frequency inflicted upon the individuals of our race; we believed it our duty to construct a permanent shield in the service of our Spanish countries as an alert against all of the illegal advances in the past and present towards absorbing them, outrageously taking them by surprise to extermination and death, and annihilating the nationalities of the invaded peoples.... All of the individuals of the diverse Spanish nationalities in California, in honor of our race, should protect it [the Spanish-language press] ...xxi

What is also notable about this stance-which was presumably held by Ramírez as well, for he states that Jofre's editorial "has much truth and sane judgment"-was that the oppression of Hispanic peoples in California is placed within the perspective of U.S. territorial expansion in the hemisphere.

The editorials of Francisco P. Ramírez certainly were a basis for the development of a Hispanic ethnic minority consciousness in the United States; his influence in disseminating that point of view in the native population and raising its consciousness as a people cannot be underestimated: "The very force of occupation brought the first notions of Mexican American nationalism and resistance in the nineteenth century-predating the Chicano Movement by about one hundred years. The concept of Francisco P. Ramírez, through his Los Angeles Spanish weekly El Clamor Público, proposed the term La Raza to denote Mexican Californians." xxii Historians have 


\section{Ethnic Studies Review Volume 21}

also seen him as a pioneer in the struggle for civil rights for Mexican Americans and Hispanics in the United States:

El Clamor Público was a public defender speaking out against unfair administration, the manipulation of juries, corrupt practices, and prejudiced application of the law. It also sought to inform and instruct the Mexican people on civics as well as the basics of statue and emigration law.... Ramírez loudly and frequently stated that though life had been poorer, matters were a lot better off before 1848, and he used a phrase that would be heard again, this land is our land.xxiii

In summary, Ramírez seems to have been the first Mexican American journalist in the West and Southwest to consistently use the press to establish a nativist perspective and to pursue civil rights for his people.

In many ways, Los Angeles' La Crónica, on which Ramírez worked for a while, became asuccessor to El Clamor Público. The major investor in La Crónica was Antonio Coronel, a major figure among Californios, a business and political leader who had served in the militia and was an administrator of missions and a judge during the Mexican period. During the American period, he was an elected councilman, a county assessor, and even mayor. When he founded La Crónica in 1872 he had just finished a four-year term as state treasurer.xxiv Coronel was a devout believer in democracy and majority rule; however, he became involved more and more in the struggle to stem the tide of dispossession of Californio land and culture. His activism for the preservation of the Spanish language was formalized in 1856, when he petitioned the Los Angeles school board for bilingual education, a request that was ultimately denied. He continued to insist on the use of the Spanish language in the public sphere because of its importance for business and commerce and its importance in serving the public. His support of La Crónica must be seen as part of his commitment to the language and culture of the California native Hispanics. Coronel himself and the majority of Mexican Americans in the Southwest at this time were Republicans. As former citizens of Mexico, where slavery had been abolished 
since 1821, they identified with the Union during the Civil War. Indeed, many of them were of mixed Indo-Afro-Hispanic heritage. Their "race" was continuously under attack. Antonio Coronel himself had been subjected to racial slurs from his Democratic opponents in the mayoral race of 1856 .

Throughout its issues, La Crónica not only defended Mexican Americans against racism but waged a battle for cultural preservation. And preserving the Spanish language, again, was at the heart of preserving the culture. In its February 24, 1877, issue, for instance, La Crónica bemoaned the trend of Mexican Americans losing their ability to speak Spanish and specifically called upon the Spanish-language press to take on the defense of Spanish as part of its community mission. La Crónica, as holder of the concession for printing public notices in Spanish for the city government, had an official role in this regard.

In insisting on integration into the American education and political system and on learning the English language for survival, while promoting the preservation of Hispanic culture and the Spanish language, El Clamor Público and La Crónica and most of the other Spanish-language newspapers of California in the three decades after statehood created a firm basis for the development not only of an ethnic minority identity but also of biculturalism - which is precisely what Hispanics advocate today in the United States.

\section{Arizona}

Two newspapers were noteworthy in Arizona for developing a sense of Americanism and entitlement of the Mexicano-origin population. Tucson's El Fronterizo (18781914) and El Tucsonense (1915-1957). Founded by Carlos Velasco, an immigrant businessman from Sonora, Mexico, El Fronterizo covered news from both sides of the ArizonaSonora border and developed a sense of regionalism, catering to the needs of the mining communities in the area as well as to the business interests of the Tucson community. It was progressive and it promoted modernization of the region and pacification of the local Indian tribes-often in virulently genocidal terms! But more than anything, Velasco, who had been a sen- 


\section{Ethnic Studies Review Volume 21}

ator and superior court judge in Sonora, xxv advocated Mexican American voting and participation in the political system:

The raza because of its respectable numbers in Arizona, could well partake of the greatest amount of guarantees, if they had their just representation in the more important public posts. But in a very injurious manner it seems that, with a few honorable exceptions, the raza has resigned itself to licking the chain which binds it to the controlling powers of those who would take advantage of their ignorance and disunity, those who do not retum the service rendered, nor judge them worthy of any kind of consideration...xxvi

Like most of the Mexican American newspapers in the Southwest, El Fronterizo was aligned with the Republican Party; however, it would customarily endorse Democratic candidates if they were Hispanic and potentially increase the representation of Hispanics.

What made El Fronterizo a particularly notable milestone in the development of a Mexican American ethnic minority consciousness was that its editorials and stories supported the civil rights agenda of the Alianza Hispano Americana (The Hispanic American Alliance), the longest lived Mexican American mutualist and civil rights organization, not coincidentally founded by the newspaper's intellectual publisher, Velasco. According to Gómez-Quiñones, "El Fronterizo published perhaps the clearest and strongest advocacy for Mexican electoral and civil rights of any southwestern newspaper in the 1870s." xxvii Velasco also campaigned tirelessly against discrimination throughout the Southwest and suffered "enmity, poverty and insult in defending the people of his race."xxviii

Although Velasco was a prime mover in the Alianza and the founder of El Fronterizo, it was a rancher who traced his lineage back to the Spanish colonists of the area, Ramón Soto, who was able to articulate best the ethnic minority ideology that would solidify the community. And he did it with three 
essays that he published in El Fronterizo in July 1892. Soto called for Mexicans in Arizona to unite and set aside their differences in order to vote as a block for Mexican candidates. $\mathrm{He}$ asserted their entitlement rights in order to combat the disenfranchisement that could come from considering themselves foreigners:

All of us in general believe that this country is the exclusive property of the Americans, any one of whom arriving from New York, San Francisco or Chicago has the right to be sheriff, judge, councilman, legislator, constable or whatever he wants.... Such an American can be Swiss, Italian, Portuguese or whatever. Always, in the final analysis, he is an American. And ourselves? Are we not American by adoption or birth? Of course we are. And as sons of this country, being born here, do we not have an equal or greater right to formulate and maintain the laws of this land that witnessed our birth than naturalized citizens of European origin? Yes. Nevertheless the contrary occurs. Why? Because of the indifference with which we view the politics of this country. Erroneously possessing a patriotic feeling for our racial origins, our interests are here yet our souls remain in Mexico. This is a grave error, because we are American citizens ....xxix

Sheridan believes that Soto's essays and speeches were very influential in getting the Mexican American community to refocus and to realize once and for all that its destiny was truly in the United States and that it had to concentrate on bettering the conditions of Mexicans here; he even purposefully referred to the community not as the "Mexican colony" but as the "Hispanic American colony" in order to bring the community into the mainstream of life in the United States, much as European immigrant groups had been doing in their adopted country.xxx 


\section{Texas}

A few Texas Mexican newspapers in the 1850s on occasion assumed activist roles, such as San Antonio's El Bejaraño (The Bejar County, 1855-18_?), whose masthead proclaimed "dedicado a los intereses de la población MéxicoTejana" (dedicated to the interests of the Texas Mexican population). While clearly helping to define the interests of the native Mexican population and taking the lead on such issues as teaching Spanish in the public schools (1 February 1855) and defending the rights of Mexican American teamsters to do business (13 February and 5 March 1855), El Bejareño was far from articulating the rights of Mexican Americans and it never assumed the aggressiveness that Francisco P. Ramírez had. Towards the end of the century there were a number of newspapers in Texas that represented Tejano issues and culture. El Regidor (The Regent, 1888-1916), founded in San Antonio by Pablo Cruz, was just such a journal. In 1901, Cruz took on the cause of an unjustly accused and condemned Tejano, Gregorio Cortez, not only in the pages of the paper but also in the community by raising funds for this victim of culture conflict who was soon elevated to legendary hero status by the Tejano folk. Through Cruz's efforts, Anglo lawyers were hired for Cortez's defense, and after one appeal after another and various changes of venue to avoid local prejudices, Cortez was eventually found innocent of murdering a sheriff.

An important figure in establishing a Texas Mexican identity and fighting for Tejano rights was the militant journalist Catarino E. Garza. Born on the border in 1859 and raised in or around Brownsville, Garza was educated in both the United States and Mexico and worked in newspapers in Laredo, Eagle Pass, Corpus Christi and San Antonio. In the BrownsvilleEagle Pass area, he became involved in local politics and published two newspapers, El Comercio Mexicano (Mexican Commerce, 1886-?) and El Libre Pensador (The Free Thinker, 1890-?), which "criticized the violence, usurpation, and manipulation suffered by Mexican Americans." $x x x i$ Beginning in 1888, when he confronted U.S. Customs agents for killing two Mexican prisoners, Garza became more militant and struck out at authorities on both sides of the border, including the repre- 
sentatives of dictator Porfirio Díaz, with a band of followers that included farmers, laborers, and former Texas separatists. A special force of Texas Rangers eventually broke up his force of raiders, and Garza fled in 1892 to New Orleans and from there to Cuba and Panama, where he was reportedly killed fighting for Panamanian independence from Colombia. Garza's exploits were followed in detail in the Spanish-language newspapers of the Southwest and helped to coalesce feelings about exploitation and dispossession among the Mexican American population. This process was also abetted by the reprinting of Garza's articles in newspapers throughout the Southwest.

One of the most influential newspapers along the border was Laredo's La Crónica (The Chronicle, 1909-?), written and published by Nicasio Idar and his eight children. Nicasio Idar had been a railroad worker and one of the organizers of a union of Mexican railroad workers in Texas: La Alianza Suprema de Ferrocarrileros Mexicanos. As a publisher, he never abandoned his working-class and union background. He and his family took the forefront in representing the rights of Texas Mexicans. In the pages of La Crónica and a magazine they published, La Revista de Laredo, he promoted the defense of the native Mexican population and their civic and political projects. Idar was in the vanguard, establishing Mexican schools for children in Texas. His daughter, Jovita Idar, was at the forefront of women's issues and collaborated in a number of women's periodicals. One of his sons followed in his footsteps and went off to Colorado to help in organizing miners. La Crónica decried everything from racism to negative stereotypes. It also leveled criticism at factionalism and bloodshed in revolutionary Mexico. Idar, however, saw the Revolution as an opportunity for Texas Mexicans and Mexican immigrants to unite and reconquer their lands and thereby enjoy greater freedom.

La Crónica was opposed to the more internationalist and radical efforts of Regeneración and the Brothers Flores Magón. However, Idar headed up a political movement of his own: El Primer Congreso Mexicanista (The First Mexicanist Congress). The Congress, which met in Loredo (from September 14 to 20), had as its main purpose the unification among all Mexicans in the state of Texas in order to battle 


\section{Ethnic Studies Review Volume 21}

injustice. According to Gómez Quiñones, such action was to be premised on a consensus that would arise from addressing the following questions: (1) Mexican civic consciousness, that is "nationalism" in the community; (2) trade union organizing; social and education discrimination; (4) the role of the Republic of Mexico's consular offices and relations with consuls; (5) the necessity of community-supported schools to promote Spanish-language and Mexican cultural instruction by Mexican teachers; (6) strategies and tactics to protect Mexican lives and economic interests in Texas; and (7) the importance of women's issues and organizations for improving the situation of "La Raza." In part a civil rights agenda, the program was a combination of questions or themes as well as organizing and advocacy priorities that took into account cultural, economic and political aspects. ${ }^{x x i i}$

The Congress, which had attracted some four hundred delegates from organizations throughout the state, concluded with the founding of La Gran Liga Mexicanista (The Great Mexicanist League), an association of organizations that promoted the nationalist ethos of "Por la raza y para la Raza" (By the People and for the People). The Congress also founded the women's association of the movement, the Liga Femenil Mexicana (League of Mexican Women), in which Jovita Idar took a leadership role.

Another newspaper that served the Tejano community was San Antonio's El Imparcial de Texas (The Texas Impartial, 1908-1924), which found new readers in the large influx of refugees from the Mexican Revolution. Founded by a druggist from the border, Francisco A. Chapa, who had been educated at Tulane University in New Orleans and settled in San Antonio in 1890, El Imparcial de Texas was strictly a business venture of a man who had gained the reputation in both Anglo and Mexican communities of being a progressive man of science, interested in education; he was so well thought of that he was 
elected treasurer of the board of education and a member of the Business Men's Club. Chapa, nevertheless, had a political commitment to the Mexican American population, and used his newspaper to promote electoral activism as well as to celebrate Mexican American contributions to the World War I effort at a time when Mexican American loyalty was in question among Anglos. Chapa was called upon by Anglo politicians to get the Mexican American vote behind them and became a man of considerable power and influence.xxxiii

Journalistically one of Chapa's most valuable contributions may have been his hiring of Ignacio E. Lozano as business manager for the newspaper. Lozano went beyond the business side of the operation and began writing editorials and writing up news items, and by 1911 he was the main force behind El Imparcial de Texas. Ultimately Lozano broke with El Imparcial, possibly because it primarily served Mexican Americans, and Lozano saw the need for a grander, more professional newspaper that would encompass the large immigrant community. The daily newspapers that were founded in the major urban centers of the Southwest by Mexican immigrant publishers soon displaced many native Mexican American ones, although the natives' issues and perspectives were also assimilated and represented in many of these papers, as much as they were in La Prensa. In smaller towns and cities, nativist efforts were able to survive into the postWorld War II era and the open recognition of a Mexican American identity.

A broader reading of the hundreds of Spanish-language newspapers published in the Southwest from the mid nineteenth century until World War II will substantiate that an ethnic minority and sometimes a "racial" minority consciousness was developing indeed. More importantly, thousands of readers in Southwestern communities were consuming and assimilating these ideas for decades. Further reading of periodicals will show that these rudimentary nineteenth century perspectives made their way into English-language publications and into the stances that the major civil rights organizations assumed from World War II period to the present. 


\section{NOTES}

i Lubomyr R. Wynar and Anna T. Wynar in Encyclopedic Dictionary of Ethnic Newspapers and Periodicals in the United States $_{1} 2$ d. ed. (Littleton, CO: Libraries Unlimited, Inc., 1976), 14-19. I agree in general with their use of the term "ethnic" as an all inclusive term, but I would insist that the sub-categories of "exile," "immigrant," and "ethnic minority" are necessary for Hispanic press. The Wynars, moreover, treat the African American, Native American, and Hispanic presses solely as ethnic regardless of their special function as expression for the oppressed minorities. Also see Sally M. Miller, ed. The Ethnic Press in the United States: An Historical Analysis and Handbook (Westport, CT: Greewood Press, 1987); Dirk Hoeder, ed. The Immigrant Labor Press in North America, 1840s - 1870s (Westport, CT: Greenwood Press, 1987); Victoria Goff, "Spanish-language Newspapers in California," in Outsiders in 19th Century Press History: Multicultural Perspectives, ed. Frankie Hutton and Barbara Reed (Bowling Green State University Popular Press, 1995), 55-70; Robert E. Park, The Immigrant Press and Its Control (New York: Harper \& Brothers, 1922).

ii Tomas Almaguer, Racial Fault Lines: The Historical Origins of White Supremacy in California (Berkeley: University of California Press, 1994), 3.

iii Bernardo P. Gallegos, Liberty, Education, and Society in New Mexico, 1693-1821 (Albuquerque, NM: University of New Mexico Press, 1992), 53. According to Gallegos, roughly one third of New Mexico society was literate in the early nineteenth century.

iv Henry R. Wagner, "New Mexico Spanish Press," New Mexico Historical Review 12/1 (January, 1937), 2-3, presents an indepth discussion about the founding of both El Crepúsculo de la Libertad in Santa Fe and the El Crepúsculo, another newspaper published in Taos by the important historical figure Father Antonio José Martínez. Also see Félix Gutiérrez, 
"Spanish-Language Media in America: Background, Resources, History," Journalism History 4:2 (Summer, 1977), pp. 37-38.

$v$ There is some indication that a bilingual English-Spanish newspaper might have been published in San Antonio, Texas, during the 1820s, but no extant copies have been found. A prospectus dated 9 April 1823 announced that an American named Ashbridge would be issuing the Texas Courier every Wednesday morning beginning 16 April in English and Spanish. Stephen F. Austin expressed joy in a letter dated 20 May 1823 upon hearing of the newspaper, but documents show that if any issues were ever published the newspaper would have ceased publication by July because that was when Ashbridge's press was shipped to Monterrey, Mexico, following its sale on 13 June 1823. Another newspaper of which no copies have been found is Mexican Advocate published in Nacogdoches in 1829. It might been a bilingual newspaper. See John Melton Wallace, Gaceta to Gazette: A Check List of Texas Newspapers, 1812 -1846 (Austin, TX: University of Texas Department of Journalism Development Program), 42, 64.

vi William B. Rice, The Los Angeles Star, 1851-1864 (Berkeley: University of California Press, 1951), 17-24.

vii See Porter A. Stratton, The Territorial Press of New Mexico, 1834-1912 (Albuquerque, NM: University of New Mexico Press, 1969), 12.

viii Gutierrez, 39. He points out how Tubac Arizonian (3 November 1859) praised the "educated Mexicans" who were "American in sentiment and feeling and [how] they, with leading Americans, control the masses;" and how Tucson's EI Forenterizo (The Frontier Journal, 11 May 1879) reprinted an article from Arizona Citizen, complimenting the Spanish-language newspaper for being "the organ of the good Mexicans."

ix Gabriel Meléndez, So All Is Not Lost: The Poetics of Print in 
Nuevomexicano Communities, 1834-1958 (Albuquerque, NM: University of New Mexico Press, 1997), 24-5. Meléndez's book is the most thorough and deeply interpretive study ever performed on any segment of Hispanic print culture in the United States.

x Gutierrez, 41.

xi Juan Gomez-Quinones, Roots of Chicano Power, 1600-1900 (Albuquerque, NM: University of New Mexico Press, 1994), 223-8. Aslo see E.B. Fincher, Spanish Americans as a Political Factor in New Mexico, 1912-1950 (New York: Arno Press, 1974); Calvin Horn, New Mexico's Troubled Years: The Story of the Early Territorial Governors (New Mexico: Horn and Wallace, 1963); Robert W. Larson, New Mexico's Quest for Statehood (Albuquerque, NM: University of New Mexico Press, 1968).

xii Melendez, 26.

xiii Melendez, 28.

xiv Melendez, 29.

xv Melendez, 30.

xvi Doris Meyer, Speaking for Themselves: Neomexicano Cultural Identity and the Spanish-Language Press, 1880-1920 (Albuquerque, NM: University of New Mexico Press, 1996), 110.

xvii La Voz del Pueblo, 7 June 1890.

xviii Melendez, 198.

xix The standard text describing this process is Leonard Pitt's The Decline of the Californios: A Social History of the Spanish- 
Speaking Californians, 1846-1890 (Berkeley: University of California Press, 1966).

xx Michel C. Neri, "A Journalistic Portrait of the SpanishSpeaking People of California, 1868-1925," Historical Society of Southern California Quarterly 55 (Summer 1973): 193-208. Neri chooses the year 1868 as the turning point in Mexican American cultural identity in California.

xxi Roberto Treviño, in his "Becoming Mexican American: The Spanish-Language Press and the Biculturation of Californio Elites, 1852-1870" (Stanford: Stanford University History Department Working Paper Series No. 27, 1989), 8-13.

xxii In the Spanish original Ramirez refers to "raza Espanola" not in its traditional Spanish sense of "people," but in the Anglo-American sense of race as a biological, not cultural, classification of people.

xxiii D.J. Jofre, "El Periodismo en California (Journalism in California)," El Eco del Pacifico, 23 February 1886.

xxiv F. Arturo Rosales, Chicano! The History of the Mexican American Civil Rights Movement (Houston: Arte Público Press, 1996), 18.

xxv Gomez-Quinones, 218.

xxvi Gomez-Quinones, 233-4.

xxvii See Estelle Lutrell, Newspapers and Periodicals of Arizona, 1859-1911 (Tucson: University of Arizona Press, 1950), 100.

xxviii Gomez-Quinones, 268.

xxix Gomez-Quinones, 268. 
Ethnic Studies Review Volume 21

xxx From Tomás Serrano Cabo, Velasco's biographer, in Crónicas: Alianza Hispano Americana (Tucson: Alianza Hispano Americana, 1929), 278-9; translated and cited by Thomas E. Sheridan, Los Tucsonenses: The Mexican Community in Tucson, 1854-1941 (Tucson: University of Arizona Press, 1986), 103.

xxxi Translated by Sheridan, 109-10.

xxxii Sheridan, 110.

xxxiii Gomez-Quinones, 291, 315-16.

Nicolás Kanellos is the Director of Arte Publico Press at the University of Houston. 